REFLECTIONS:

NEUROLOGY AND

THE HUMANITIES

Section Editor

Anne W. McCammon,

MD, FAAN

Namrata Gumaste, BA

Correspondence to

N. Gumaste:

nvg2103@columbia.edu

\title{
On Your Mother's Passing Psychosis, Self-Portrait With
}

\section{ON YOUR MOTHER'S PASSING}

The world becomes so small when we remember there is no space wider than that of grief. ${ }^{1}$ When I was young I thought lightning could be caught, taken apart \& placed in a jam jar, firefly-like in principle, Jacob's ladder-like in mystery. But the greatest things don't break down into parts half here $\&$ half there. Only moving bodies across the horizon, only stationary bodies, only things that we have $\&$ things that get lost. It's so easy to get lost. Maybe there's a safe place, the hundred miles from the coast where water bounds up against water, so there's no edge, no sinking abyss. But I don't think you should go. Listen, leave the boats anchored. It's okay to open your mouth to speak, realize everything you want to say is guttural, $\&$ there are no proper words.
PSYCHOSIS, SELF-PORTRAIT WITH

At noon, the ocean draws so far back there is only a graveyard of exoskeletons. Underground, the water moves capillary-like through roots. A deeper shadow has eclipsed my earth. You must understand, many nights have been long for me; a small portion of myself was taken, a small portion like glowing orbs undulating in the distance. The hours fall Jacob's ladder-like in a maze.

Let's talk about the mind. Into that darkness, into the cerebral noise, I hear rummaging even when alone: I prefer myself in the singular.

Can you see the way the sky opens white before the storm? The brain works in strange ways, imagines a limb felled in the road.

In tin roof shacks, I speak

Hail Marys caught through teeth, a stuck switch. Focus on my fall now, the way force torques me left to right.

I remember seeing myself once, seven times over between two mirrors, thinking this is me $\&$ this is me $\&$ this $\&$ this $\&$ this $\&$ this $\&$ this.

\section{REFERENCE}

1. Neruda P. The Poetry of Pablo Neruda. Stavans I, ed. New York: Farrar, Straus, and Giroux; 2003. 


\title{
Neurology
}

\section{On Your Mother's Passing; Psychosis, Self-Portrait With \\ Namrata Gumaste \\ Neurology 2016;87; 247 \\ DOI 10.1212/WNL.0000000000003348}

This information is current as of November 21, 2016

\author{
Updated Information \& \\ Services \\ including high resolution figures, can be found at: \\ http://n.neurology.org/content/87/21/e247.full \\ Subspecialty Collections \\ This article, along with others on similar topics, appears in the \\ following collection(s): \\ Psychosis \\ http://n.neurology.org/cgi/collection/psychosis \\ Permissions \& Licensing \\ Information about reproducing this article in parts (figures,tables) or in \\ its entirety can be found online at: \\ http://www.neurology.org/about/about_the_journal\#permissions \\ Reprints Information about ordering reprints can be found online: \\ http://n.neurology.org/subscribers/advertise
}

Neurology ${ }^{\circledR}$ is the official journal of the American Academy of Neurology. Published continuously since 1951 , it is now a weekly with 48 issues per year. Copyright @ 2016 American Academy of Neurology. All rights reserved. Print ISSN: 0028-3878. Online ISSN: 1526-632X.

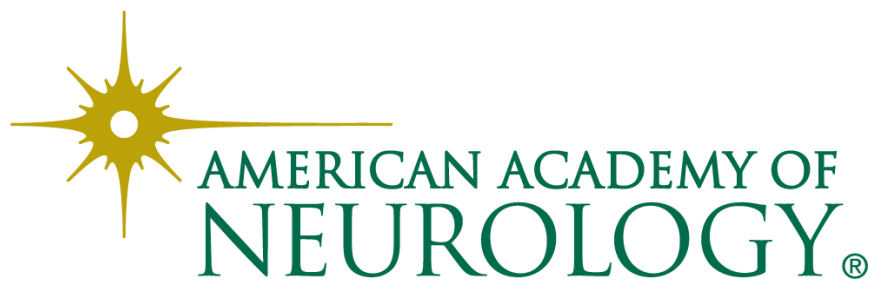

